Bojan Godeša*

\title{
Reconciliation instead of History ${ }^{1}$
}

\section{IZVLEČEK \\ SPRAVA NAMESTO ZGODOVINE}

Razprava obravnava vprašanje sprave, ki je od srede osemdesetih let prejšnjega stoletja v slovenski družbi postajalo vse bolj prisotno in je vrhunec doseglo s slovesnostjo v Kočevskem rogu julija 1990. Že pred tem sta izjavi o tem vprašanju podala predsedstvo SRS in slovenska pokrajinska skofovska konferenca, ki pa sta se usebinsko znatno razlikovali. Predsedstvo SRS je poudarjalo, da je smisel narodne in državljanske umiritve predvsem v vzpostavitvi "takih razmer v političnem in javnem življenju Slovenije, ko preteklost ne bo več obremenjevala medčloveških odnosov«, medtem ko je izjava škofovske konference poudarjala, da "edino resnica nas more osvoboditi, biti podlaga za spravo in omogočiti pot $k$ pomiritvi«. Različno razumevanje vprašanja sprave je $v$ zadnjih petindvajsetih letih privedlo do tega, da se nasprotja in ideološke delitve v slovenski družbi z vsako spravno deklaracijo le še poglabljajo.

Ključne besede: druga svetovna vojna, sprava, kulturni boj, zgodovinopisje, revizija

\section{ABSTRACT}

The discussion focuses on the issue of reconciliation, which had become increasingly notable in the Slovenian society since the middle of the 1980s and culminated in the ceremony in the Kočevski rog forest in July 1990. Even before that solemn event, the Presidency of the Socialist Republic of Slovenia and the Slovenian Regional Episcopal Conference gave statements with regard to this issue, which, however, differed from each other significantly. The Presidency of the Socialist Republic of Slovenia emphasised that the purpose of the national and civil appeasement was especially to establish "such a situation in the political and public life of Slovenia where the past no longer represents a burden for interpersonal relations", while the statement of the Episcopal Conference underlined that "only the truth can set us free, represent the basis for reconciliation, and pave the way towards appeasement". In the last twenty-five years the different ways of understanding the question of reconciliation led to the oppositions and ideological divisions in the Slovenian society deepening even further with every reconciliatory declaration.

* Research Counsellor, PhD, Institute of Contemporary History, Kongresni trg 1, 1000 Ljubljana, Slovenia, bojan.godesa@inz.si

1 Braco Rotar, "Sprava namesto zgodovine," ["Reconciliation Instead of History"] Razgledi, 27 May 1994. 
Keywords: World War II, reconciliation, cultural struggle ("Kulturkampf"), historiography, revision

On 8 July 1990 a ceremony took place in the Kočevski rog forest, attended by the highest representatives of the political and public life, including the President of the Presidency of the Socialist Republic of Slovenia. The Metropolitan Archbishop Dr Alojzij Šuštar held a mass. The solemn event was supposed to be the "first step towards appeasement, so very important for the Slovenian nation and its state", which would contribute to the "establishment of such a situation in the political and public life of Slovenia where the past no longer represents a burden for interpersonal relations". ${ }^{2}$

Before that, on 4 March 1990, the Presidency of the Socialist Republic of Slovenia published a statement on the national and civil appeasement, ${ }^{3}$ substantiated with the words "that in this serious and pivotal moment of the transformation into a pluralist democratic system we are obliged to address the issue which the public sees as the problem of the "national reconciliation"'. ${ }^{4}$ In the opinion of the Presidency of the Socialist Republic of Slovenia, the purpose of this discussion should be to

"contribute to the establishment of such a situation in the political and public life of Slovenia where the past no longer represents a burden for interpersonal relations of today and tomorrow. This is the problem of the national and civil appeasement 45 years after the end of the war. In the interest of public well-being, the national politics should aim to eliminate any possibility of a contemporary division of the society." 5

The statement of the Presidency of the Socialist Republic of Slovenia represented a substantial turning point in the attitude towards reconciliatory processes, as it elevated this issue to the level of state institutions. Namely, until then the reconciliatory initiatives had come exclusively from the ranks of the civil society.

On 9 May 1990 (in April 1990 the first free and democratic elections in Slovenia after 1927 took place), the newly-elected President of the Assembly France Bučar opened his inaugural address with the following words:

2 Božo Repe, Viri o demokratizaciji in osamosvojitvi Slovenije. 2. del. - Slovenci in federacija [Resources on the Democratisation of Slovenia and its Attainment of Independence. Part 2 - Slovenians and the Federation] (Ljubljana: Arhivsko društvo Slovenije, 2003), 21.

3 The statement was drawn up on the basis of a draft, written by the historian Janko Pleterski, a member of the Presidency of the Socialist Republic of Slovenia (1988-1990). Pleterski later explained his attitude towards reconciliation in the article "O NOB in spravi," ["On the National Liberation Struggle and Reconciliation"] in: Narodnoosvobodilni boj v slovenskem narodnem spominu. Slovenski zbornik 2007, eds. Janez Stanovnik et al. (Ljubljana: GO ZZB NOB Slovenije, 2007), 23-31.

4 "Narodna umiritev kot pogoj za mirno sožitje" ["National Appeasement as a Condition for Peaceful Coexistence"], Delo, 5 March 1990, 1, 2.

5 Ibid. 
"More than feeling dutifully thankful for the trust invested in me as I was chosen to be the President of this respectable Assembly, I am, above all, thoroughly shaken by the awareness of the historical and fatal importance of the turning point that the current moment represents for the Slovenian nation. By constituting this Assembly we can assume that the civil war that has been beleaguering and hindering us for almost half a century is finally at an end."6

In such an atmosphere the newly-elected President of the Presidency of the Republic of Slovenia Milan Kučan, in his address of the Members of Assembly, explained the reasons for the necessity to carry out the reconciliatory process with the following words:

"The Presidency of Slovenia recently adopted a statement on the national and civil appeasement. This was soon followed also by the statement of the Slovenian Episcopal Conference on the national reconciliation. These actions went a long way towards the reconciliation of all Slovenians and towards ensuring a rightful peace among us, in order to prevent the foreboding ghosts of the past - divisions, treason, hatred and civil war - from still being summoned today. The purpose of the reconciliation, which is a historical necessity and our cultural and civilisational duty, is to eradicate our painful obsession with the past, because we must live on. Nations preoccupied with the past threaten their present and give up their future. Reconciliation can neither be achieved nor experienced by those who keep hating. We can only achieve it by consciously and responsibly refraining from inciting new hatred from the old ashes. Without trying to fix or conceal our history, we are duty-bound to correct the injustice where that is still possible and apologise to each other for whatever was wrong with our actions during the war and after it. The whole nation can come to terms with its own history only if we allow history to finally become the past, if we finally bury our dead, and if we forgive. (...) I am firmly convinced, as are all members of the Presidency of Slovenia, that this very Assembly, in this form and in this pivotal time, has been called upon to finally take this historical step, so crucial for our nation, and acknowledge that all Slovenians are entitled to their homeland. We should prevent any of the future generations, born into the world burdened by the hatred of others, from having to endure the task of purification, reconciliation and appeasement."7

A few days after the statement of the Presidency of the Socialist Republic of Slovenia, but still before the elections in April, at a session on 13 March 1990 the Slovenian Regional Episcopal Conference released a Statement on the National Reconciliation as well. ${ }^{8}$ In the introduction this Statement welcomes the gesture of the Presidency of the Socialist Republic of Slovenia as an important step towards "ad-

6 Rosvita Pesek, Bučar (Celovec/Klagenfurt: Mohorjeva, 2016), 186, 187.

7 Milan Kučan's address of the Members of the Assembly of the Republic of Slovenia on 9 May 1990, after the first free parliamentary democratic elections in Slovenia, acquired on 5 September 2016, http://www2.gov.si/up-rs/2002-2007/bp-mk.nsf/dokumenti/09.05.1990-90-92.

8 France Martin Dolinar, Resnici na ljubo. Izjave ljubljanskih škofov o medvojnih dogodkih [Truth Be Told. Statements of the Ljubljana Bishops about the Wartime Events] (Ljubljana: Družina, 1998), $31-34$. 
dressing this vital question and the future of the Slovenian nation". However, at the same time it emphasises that "in our statement we do not want to comment on the individual claims of the Presidency's statement. A public discussion should contribute to this." The Statement goes on to say:

"In the opinion of the Slovenian Regional Episcopal Conference, appeasement is a goal that the Church shall pursue to the best of its ability, and it wishes to honestly cooperate with everyone who holds this goal dear. However, appeasement cannot be ordered or forced. Reconciliation is the only path towards this goal, and without it there cannot be a permanent and true appeasement. Therefore reconciliation is the first and most crucial task. (...) As far as this is concerned, we should first take into account the reconciliation with the dead and then the reconciliation with the living. The latter cannot exist without the former. (...) In order to ensure the reconciliation among the living - the only way to ensure national appeasement, we should, in our opinion (...) ascertain the full and comprehensive historical truth about all the events since the beginning of the last war until today. Only truth can set us free and serve as the basis for reconciliation, which would allow for appeasement. Thus the primary task is to objectively ascertain and publish all the facts, in so far as that is possible, on the basis of documents and testimonies. The unresolved past cannot simply be forgotten or erased, especially as until now so many fabrications have been spread, or it has not been possible to determine and reveal the truth at all."10

For the solemn reconciliatory event in the Kočevski rog forest, organised at the initiative of Spomenka Hribar, ${ }^{11}$ the Presidency of the Republic of Slovenia adopted a decision about the concept: it would be a state and Church event with a religious ceremony and two speakers (the President of the Presidency of the Republic of Slovenia and the Slovenian Metropolitan Archbishop). ${ }^{12}$

On 2 July 1990, shortly before the reconciliatory ceremony in the Kočevski rog forest, the Pravičnost in mir (Justice and Peace) commission released a statement entitled For a Deeper Understanding of Reconciliation, signed by Anton Stres. It expressed the expectations of the Roman Catholic Church in Slovenia with regard to the question of reconciliation far more directly:

"Before the funeral ceremony of those killed in the Kocevski rog forest, our community as well as the emigrant public still strongly expresses numerous and sometimes very diverse attitudes

9 Ibid. An extensive public discussion then also in fact took place. Boris Mlakar prepared the introductory foundations for the survey entitled " $Z$ narodno spravo - konec državljanske vojne?," ["National Reconciliation - the End of the Civil War?"] Borec. Revija za zgodovino, antropologijo in književnost, No. 5-6-7 (1990): 582-716, which was one of the most resounding surveys at the time.

10 Ibid.

11 Zdenko Roter, Padle maske. Od partizanskih sanj do novih dni [Masks Removed. From the Partisan Dreams to the New Days] (Ljubljana: Sever \& Sever, 2013), 412, 413.

12 Božo Repe, Milan Kučan, prvi predsednik [Milan Kučan, the First President] (Ljubljana: Modrijan, 2015), 282, 283. 
towards the so-called reconciliation. There are many misunderstandings and imprecise assessments of the intentions of either side. Therefore it is appropriate that we might once again clarify the purpose of the funeral ceremony in Kočevski rog and explain the connection between this event and reconciliation, which will undoubtedly take much longer. The Kočevski rog forest is the resting place of the people killed by the side, victorious in the war, in order to simply erase them from our memory. With the funeral ceremony we want to restore the most basic human dignity owed to the dead: that they are counted among the dead and that they have their own graves. (...) We are aware of the fact that this does not conclude, but merely begins the process of reconciliation. As it is, reconciliation cannot be ensured without truth, as thorough as possible: and the path towards this truth is still long. We will only be able to reach it by overcoming a variety of preconceptions, especially the prejudice stemming from our different ideologies. (...) Therefore we cannot agree with those who believe that the past should simply be forgotten. That would mean that we just want to cover up rather than heal the wound. Even worse: it would mean that the injustice should be left uncorrected - which is the same as agreeing to it. Of course, it is clear that it will not be possible to completely right all the wrongs. However, also for this reason we are morally bound to try and do at least what we can." 13

With this official standpoint the Roman Catholic Church in Slovenia joined the reconciliatory efforts and started acting as an advocate of the undisclosed victims' interests. In relation to the state it attempted to assert itself as an equal partner and partly also as the only true representative of the Slovenian nation or at least as its supreme moral authority.

A variety of civil initiatives may have surfaced with regard to the question of reconciliation, at least in the initial period, for example those proposed by the United under the Linden Tree of Reconciliation civil society (Združeni ob lipi sprave, Stanislav Klep) or the New Slovenian Covenant (Nova slovenska zaveza). However, these were more or less variations that were basically identical as the standpoints expressed by the leadership of the Roman Catholic Church in Slovenia in 1990.

Otherwise the reconciliation initiative had already been taken in the pivotal days of May 1945. At its session at Tabor on 3 May 1945, the National Committee for Slovenia had drawn up a "proclamation" calling upon "all Slovenians to ensure a general reconciliation in order to release and unite all the modest and weakened national forces, tied up in the internal strife, as in this historical moment they are needed for the purpose of ensuring the highest national goals". ${ }^{14}$ As it happened, the Slovenian anti-communists, in the shadow of collaboration, felt the need to call for "general reconciliation" shortly before they emigrated. At that time - as the Allies refrained from responding to all the appeals while the German authorities still remained in

13 "Za globlje razumevanje sprave. Izjava komisije Pravičnost in mir (prof. dr. Anton Stres)," ["For a Deeper Understanding of Reconciliation. The Statement of the Justice and Peace Commission (Professor Dr Anton Stres)"] Družina, 8 July 1990, 13.

14 Bože Repe, Mimo odprtih vrat. Izbrani dokumenti o dejavnosti okupatorjevih sodelavcev na Slovenskem [Past the Open Door. Selected Documents about the Activities of the Occupiers' Collaborators in Slovenia] (Ljubljana: Založba Borec, 1988), 171. 
charge - according to the President of the National Committee Jože Basaj the anticommunists realised that "this authority was only a shadow, and therefore we decided to disappear from Ljubljana as soon as possible, because the front lines were getting closer suspiciously quickly". ${ }^{15}$ Before that, throughout the period of the occupation, the two hostile camps had not appealed to any reconciliation. Only a few initiatives to negotiate a cease-fire had been undertaken, including the efforts of Lojze Ude, which had been the most sensible yet unsuccessful nevertheless. ${ }^{16}$ Among the political emigration in exile, the wish for reconciliation would sporadically appear among individual people (for example Vinko Levstik, Ciril Žebot). Otherwise the political emigration took part in the developments in its homeland mostly through the Slovenian World Congress, established at its constitutive sitting on 27 and 28 June 1991 in Ljubljana and envisioned as an "all-Slovenian organisation, connecting and uniting Slovenians at home and abroad on the basis of the dedication to Slovenianism regardless of their worldview, political and other differences." 17 The issue of the national reconciliation was at the centre of this organisation's attention ever since its establishment, and it was also listed in its statute as one of its main goals. ${ }^{18}$

After 1990, when reconciliation was the main topic for a while, this issue became less prominent as the attention of the public focused on the realisation of the Slovenian emancipation. However, the reconciliatory efforts at the time failed to overcome the ideological divisions. ${ }^{19}$ It soon became clear that they actually widened the rift.

The commemoration of the $50^{\text {th }}$ anniversary of the end of World War II in 1995 represented an important symbolical turning point in the intensification of the ideological schism. Thus the statement of the Slovenian Episcopal Conference entitled Sluziti resnici, pravici in spravi (In the Service of Truth, Justice and Reconciliation) also includes the following:

"World War II has been etched in the memory of our nation not only as a sad period of the occupation, but also as a period of the profound division of the nation and the war between brothers. This horrific wound caused by the national discord has not yet healed, and even 50 years after the end of the war we remain incapable of carrying out the essential acts of the national reconciliation. (...) We feel that the current authorities do not show enough motiva-

15 Boris Mlakar, "Protirevolucionarni tabor in konec vojne," ["The Anti-Revolutionary Camp and the End of the War"] in: Slovenska novejsa zgodovina. Od programa Zedinjene Slovenije do mednarodnega priznanja Republike Slovenije 1848-1992, eds. Jasna Fischer et al. (Ljubljana: Mladinska knjiga, 2005), 777.

16 Bojan Godeša, "Lojze Ude in poskus vzpostavitve premirja med drugo svetovno vojno," ["Lojze Ude and the Attempt to Establish a Cease-Fire During World War II"] Acta Histriae, No. 3 (2013): 283-90.

17 Documentation from the opening session of the Slovenian World Congress, Ljubljana, 27 and 28 June 1991 (Ljubljana: Slovenian World Congress, Conference for the Republic of Slovenia, 1994), 3.

18 Ibid.

19 Božo Repe, Jutri je nov dan. Slovenci in razpad Jugoslavije [Tomorrow is Another Day. Slovenians and the Dissolution of Yugoslavia] (Ljubljana: Modrijan, 2002), 127. 
tion and do not provide enough opportunities to explore our recent history and to right the injustices." 20

The interpretation of the ceremony in the Kočevski rog forest in 1990, as it was expressed at the $70^{\text {th }}$ anniversary of the end of the war by the Ljubljana Auxiliary Bishop Anton Jamnik, should be understood in light of the unrealised expectations of the Roman Catholic Church in Slovenia as well. Jamnik stated the following:

"This event was carefully orchestrated. Throughout the years, until today, it kept being launched and 'spun' by all sorts of media in Slovenia and abroad, thus creating - or, to put it more succinctly, manipulating - the public opinion, conveying an impression that the Kocevski rog ceremony was a so-called 'reconciliatory ceremony' with Archbishop Šuštar and President Kučan as partners in this reconciliation. Such an explanation in fact 'took root' among the people, but it was merely manipulation as a result of well-calculated pragmatism. It was a scam that persists even today." 21

Lojze Peterle also believes that the reconciliatory ceremony in Kočevski rog supposedly contained "elements of deception". 22 A very similar viewpoint was expressed also by Jože Pučnik at the $33^{\text {rd }}$ Draga Study Days in $1998 .^{23}$

The President of the Presidency of the Republic of Slovenia at the time, Milan Kučan, stated the following about the issue of reconciliation and the ceremony in Kočevski rog:

"How did you expect that the process of reconciliation would continue after Archbishop Alojzij Sustar and I shook hands? I saw the reconciliatory ceremony as a pious and not a political act. However, in Slovenia the opinion prevailed that this was a political problem in need of a political solution. Is this why you refused to support the Pahor's Resolution of 1997, written by Spomenka Hribar? Having learned from my experience with the reconciliatory ceremony in Kočevski rog and the intentional diminishment of its significance, my opinion was that the situation was not yet ready for such a resolution. Otherwise I think that resolutions are not the proper way of addressing this question. I see reconciliation as the maturity of the nation, capable of saying at a certain moment: This is our history, our past. It happened, with all its good and its bad. We have to take it as our own and live with it. Resolutions, symbols and

20 Dolinar, Resnici na ljubo, 34-38.

21 Anton Jamnik, "Kdor trdi, da sprava ni možna, je obupal nad človekom," ["Whoever Claims that Reconciliation is Impossible has Given Up on Humanity"] Slovenski čas (monthly supplement of the Družina newspaper), June 2015.

22 Jernej Vrtovec, Vloga nadškofa Šuštarja pri osamosvojitvi Slovenije [The Role of Archbishop Šuštar in the Attainment of the Slovenian Independence] (Celje: Društvo Mohorjeva družba, Celjska Mohorjeva družba, 2016), 96.

23 Jože Pučnik, "Sprava kot izhodišče za civilno rast Slovencev iz naroda v državo," ["Reconciliation as the Basis for the Civil Growth of Slovenians from a Nation into a State"] in: Biti to kar si. 33. študijski dnevi Draga 98, eds. Sergij Pahor, Saša Martelanc and Marij Maver (Trst: Mladika, 1999), 137,138 . 
monuments are fine, but they will not lead to any results by themselves. For as long as reconciliation is not in the interest of the politics, it will not happen. I see reconciliation especially as an intimate human act. However, I often ask myself whether anything can be more reconciliatory among Slovenians as the joint creation of the state and the current responsibility for its future. Unfortunately, Slovenian politics refused to recognise this act as an act of reconciliation. Otherwise I am convinced that what Slovenia lacks is an anti-fascist agreement, and this impedes reconciliation as I understand it. The current Slovenian politics is not able to reach such an agreement, hence the difficulties in defining the attitude towards totalitarianisms." 24

In the biography Milan Kučan, prvi predsednik (Milan Kučan, the First President), Božo Repe assesses that "the reconciliatory ceremony was one of the most sensitive as well as far-sighted Kučan's acts in his first term". 25

In accordance with the reconciliatory efforts that the Church circles associated with the demands for the clarification of the wartime events, among the historians at least some of them - this aspiration has expressed itself in a specific manner. The efforts to ensure "balance" 26 were characteristic of the first period. However, after the year 2000 demands emerged to adopt the interpretation that the opponents of the Partisan movement had established already during World War II, maintained in emigration and transplanted to their homeland with the advent of interpretative pluralism as the only credible explanation of the wartime events. In line with the principle where anti-communism equals democracy, the advocates of such theories, appearing with the motto "the triumph of the defeated", remain convinced that they are the ultimate moral victors of the internal conflict during the war. ${ }^{27}$

However, such outlook on the wartime events in fact does not bring anything new to the Slovenian historiography and, of course, the whole of the Slovenian society in the interpretative sense, and we can hardly define it as a revision. Such efforts are actually precisely opposite to what a revision should bring: new thematisation and problematisation of the wartime past. The aforementioned example of deconstructing the myths in order to construct new ones only involves the schematic, ideological and biased efforts to rehabilitate the side that lost the war: the Slovenian forces burdened with collaboration. ${ }^{28}$

In 1995 a group of historians, ${ }^{29}$ at the request of the National Assembly of the

24 "Milan Kučan," in: Slovenija in pika!, eds. Boštjan Furlan, Ožbej Peterle and Marko Balažic (Ljubljana: Cankarjeva založba, 2016), 209-11.

25 Repe, Milan Kǚan, 281.

26 Janja Slabe, "Narodna sprava v slovenskih časopisih," ["National Reconciliation in the Slovenian Press"] Borec. Revija za zgodovino, antropologijo in književnost, No. 630-634 (2006): 9-60.

27 Bojan Godeša, Spremembe v vrednotenju druge svetovne vojne na Slovenskem po padcu berlinskega zidu. Lecture at the Historical Seminar of the Scientific Research Institute of the Slovenian Academy of Sciences and Arts in Ljubljana on 12 May 2016, [Changes in the Assessment of World War II in Slovenia after the Fall of the Berlin Wall] acquired on 10 June 2016, https://www.youtube.com/ watch?v=KkpyJ2GKuI8.

28 Ibid.

29 Zdenko Čepič, Tone Ferenc, Aleš Gabrič, Bojan Godeša, Boris Mlakar, Dušan Nećak, Jože 
Republic of Slovenia, even prepared a scientific report about the contemporary history of Slovenians entitled Key Characteristics of the Slovenian Politics 1929-1955,30 which was supposed to represent the historiographical foundation for the way in which the National Assembly would address certain open questions about the recent past. However, even this attempt to elevate the discussion from the political sphere to the scientific level failed to appease the passions involved in the examination of the unresolved past.

Generally the more reconciliatory and well thought-out emphases, opposing the widespread atmosphere of the cultural struggle, were exceedingly rare. Let me underline, for example, the speech of the President of the Government at the time, Janez Janša, at Mala gora on the Day of Uprising against Occupation in April $2005^{31}$ and the discussion during the relocation of the mortal remains of Bishop Rožman to the minster in the spring of 2013. ${ }^{32}$ Even this most likely took place only because the President of the State Kučan refused to let Rožman's reburial turn into a political manifestation. 33

Throughout this time, the Federation of Associations of National Liberation War Veterans (hereinafter the ZZB) has had a clear, consistent and principled standpoint with regard to reconciliation - a term that it always uses merely in quotation marks. As it is, the ZZB uses the term "appeasement", which was already used in the Statement of the Presidency of the Republic of Slovenia. In its Statement of the Federation of War Veterans about the Values, the Presidency of the ZZB for the values of the National Liberation Struggle of Slovenia summed up its standpoint with regard to this issue at the session on 6 October 2015:

"So, what is the difference between APPEASEMENT and 'reconciliation?? The fact that the attempt to criminalise the Partisan movement is being referred to as 'reconciliation' (...) speaks for itself. (...) The wartime and post-war executions of the disarmed adherents of the occupation military and police units has often been condemned and expressly regretted by the $Z Z B^{34}$

Prinčič, Janko Prunk, Božo Repe, Anka Vidovič-Miklavčič, Peter Vodopivec and Milan Ževart.

30 Zdenko Čepič et al., eds., Ključne značilnosti slovenske politike v letih 1929-1955. Znanstveno poročilo [Key Characteristics of the Slovenian Politics 1929-1955. Scientific report] (Ljubljana: Inštitut za novejšo zgodovino, 1995).

31 Govor predsednika Vlade RS Janeza Janše |SDS, [A speech by the President of the Government of the Republic of Slovenia Janez Janša | SDS] acquired on 10 June 2016, http://www.sds.si/novica/ govor-predsednika-vlade-rs-janeza-janse-3264.

32 Jožica Grgič, "Kočljivi medvojni položaj ljubljanskega škofa. Zgodovinarja Dolinar in Godeša o Rožmanu," ["The Awkward Wartime Position of the Ljubljana Bishop. Historians Dolinar and Godeša on Rožman"] Delo, 12 April 2013, 3. Aleksander Kolednik, "Griesser-Pečarjeva: Rožman si je prizadeval, da bi narod s čim manjšimi izgubami prebrodil vojno," ["Griesser-Pečar: Rožman strived to ensure that the nation could make it through the war with as few losses as possible"] (11 April 2013), acquired on 10 June 2016, http://siol.net/novice/slovenija/griesser-pecarjeva-rozman-si-je-prizadevalda-bi-narod-s-cim-manjsimi-izgubami-prebrodil-vojno-159685.

33 Repe, Milan Kučan, 431.

34 Speaking about this issue, we should also mention the contribution written by Janez Stanovnik, the long-time President of the ZZB for the Values of the National Liberation Struggle of Slovenia, 
(...) The $Z Z B$ has frequently expressed and emphasised its non-discriminatory view to the respectful burial of all the dead. However, at the same time it has resolutely opposed the exploitation of these issues, especially the piety towards the dead, in order to reignite the ideological and political conflicts. (...) Through various manipulations, 'reconciliation' has attempted to rehabilitate the Home Guard movement and associate it with the resistance; and abusing the reverence towards the dead has become an important part of this strategy! Therefore 'reconciliation' is not a 'precondition' for appeasement, but rather its opposite." 35

The efforts to ensure reconciliation as the basic characteristic of resolving the wartime past in the last 25 years can be defined synthetically with the finding that Božo Repe used years ago as a title for a discussion of his: Reconciliation as the Cultural Struggle. ${ }^{36}$ The result of this fact is also completely evident today: with every reconciliatory declaration the conflicts and ideological divisions in the Slovenian society are only deepening. ${ }^{37}$

Who is responsible for such a state of affairs in the Slovenian society? The answer may not be completely unequivocal, as it seems that such a situation actually suits many people on both sides, in a way. However, differences were already evident in the very definition of the foundations of the reconciliatory process in the aforementioned statements of the Presidency of the Socialist Republic of Slovenia and the Slovenian Episcopal Conference. While the former focuses especially on the aspect of piety involved in reconciliation and recommends that the resolution of the pressing issues from the past be depoliticised, in this regard the Roman Catholic Church has made very resolute demands for the re-evaluation of the past, which it has supported with the line of reasoning that "only truth can set us free and function as the basis for reconciliation, which would allow for appeasement". ${ }^{38}$ Despite these very obvious differences, today it is completely clear that the core of the problem nonetheless lies especially in the manner of dealing with the past, which is still seen in a number of diverse ways in the Slovenian society. In view of the fact that until the events related to the fall of the Berlin Wall a biased image of World War II had been dominant in Slovenia, it became clear that this war should nevertheless be interpretatively updated and placed in a new balance. In fact, this should actually be beyond any doubt.

"Obvojni poboji in narodna pomiritev," ["Wartime Executions and the National Appeasement"] in: Slovenski zbornik 2014. Narodnoosvobodilni boj in današnji čas, eds. Janez Stanovnik et al. (Ljubljana: Zveza združenj borcev za vrednote NOB Slovenije, 2014), 91-99.

35 "Statement of the Presidency of the ZZB about the values of the National Liberation Struggle of Slovenia, adopted at the session on 6 October 2015," Sporočila. Zveza združenj borcev za vrednote NOB Slovenije, No. 10 (October 2015): 2, 3.

36 Božo Repe, "Sprava kot kulturni boj," ["Reconciliation as the Cultural Struggle"] in: Onstran demokracije. Izjave in stališč Liberalne akademije po letu 2005, ed. Božidar Flajšman (Ljubljana: Liberalna akademija, 2009), 93-101.

37 Bojan Godeša, "Social and Cultural Aspects of the Historiography on the Second World War in Slovenia," Sozialgeschichte und soziale Bewegungen in Slowenien / Social History and Social Movements in Slovenia. Mitteilungsblatt des Instituts für soziale Bewegungen 41 (2009): 111-25.

38 Dolinar, Resnici na ljubo, 31-34. 
However, what had at its initial stages been a completely legitimate demand to clarify the past has not developed into a constructive dialogue, aimed at a comprehensive analysis of the wartime events by means of an unbiased, scientifically irreproachable method. As it happened, the demands for "reconciliation on the basis of truth" soon turned into a struggle for the interpretative dominance in the Slovenian society and did not always adhere to scientific standards. In this sense the process was an attempt to assert the methods that Braco Rotar shrewdly described with the title of his contribution Reconciliation Instead of History ${ }^{39}$ in the survey conducted by the Razgledi magazine, entitled What Has Happened to Our History?

If we keep our distance and look at how the reconciliatory issues have developed after the time when the question of the national reconciliation became topical in the Slovenian society, especially thanks to Spomenka Hribar, and until today, we can ascertain that the predictions of the analysts of the contemporaneous State Security Service have largely come true. These analysts assessed, already back in 1986, that the "goal of the 'national reconciliation' is to ensure that the defeated forces have enough space for rehabilitation and consolidation". ${ }^{40}$

Thus it is characteristic for the advocates of the "emigrant" interpretation or, as they claim themselves, for the supporters of the new, ideologically unburdened views that they operate extremely confidently, often even aggressively; and first and foremost their side keeps bringing up the topics that should supposedly still be studied or re-evaluated. In a part of the Slovenian historiography the emigrant explanation has in fact asserted itself as a credible interpretation of the wartime events. In the name of the "struggle for the truth", ever since the ideological relaxation in the middle of the 1980s its advocates have in fact - by selectively emphasising certain topics - dictated the orientation according to which the developments during World War II in Slovenia should be understood.

On the other hand, after the fall of the Berlin Wall the left has suffered an identity crisis and gone on the defensive: it seems as if it lacks any vision and that it is unable to find solutions to problems, related to the attitude towards the past which is seen as disputable by the society. Many adherents of the left have experienced significant difficulties with accepting the fact that interpretative pluralism has become completely legitimate also in the Slovenian society. Therefore - at least as far as the exploration of the ambiguous periods of the recent history is concerned - one of the basic characteristics of the representatives of the left is their exceedingly defensive posture. In the interpretative sense it is also possible to note a lack of innovative approaches in the substantive as well as methodological sense.

However, in contrast with such trends, visibly present in the Slovenian society, the newest analyses of this issue, carried out by the author of this text, have refuted

39 Rotar, "Sprava namesto zgodovine."

40 SI AS 1931, box 3085, "Nacionalno pomirenje" kao deo taktike unutrašnjeg i spoljnjeg neprijatelja (analitički osvrt) ["National Reconciliation" as a Part of the Tactics of our Internal and External Enemy (Analytical Viewpoint)”]. Belgrade, 4 March 1986. 
the "emigrant" theory in its entirety: not only as biased and black-and-white, but also as a completely implausible explanation without any basis in scientifically-verifiable facts. ${ }^{41}$

The most blatant example of imposing such interpretations, historically completely preposterous according to the scientific standards, expressed itself in the demand for the renewal of the proceedings against the Ljubljana Bishop Dr Gregorij Rožman. As it was, the rehabilitation of Bishop Rožman had been the primary goal of the Roman Catholic Church in Slovenia all along. Janko Pleterski commented on these endeavours with the following words: "By no means will they let the man 42 remain in history, they would rather forge him into a weapon for their current political struggle, use him as an object, a kind of a battering ram, for this struggle." 43 Ever since 1995 official efforts had been invested in the exhumation of Rožman's mortal remains and reburial in his homeland, and the precondition of the Church was his rehabilitation, as "first we have to annul the unjust process against Rožman - otherwise Bishop Rožman should remain buried at the Franciscan cemetery in Lemont". ${ }^{44}$ In the context of the imposition of such conditions, the Vatican State Secretary Cardinal Angelo Soldano explained the viewpoint of the Vatican in written correspondence with the then President of the State Kučan, "that the reburial should depend on Rožman's legal and political rehabilitation". 45 Naturally, such endeavours do not only call for the reevaluation of Rožman's wartime role, but rather, in view of the symbolic significance and his vital role in the time of the occupation, also for the rehabilitation of all that he stood for during the war. One of the key arguments for the proposal on the renewal of the judicial process against Rožman was the alleged "new evidence". This evidence supposedly exonerated the convicted Bishop, of course. Some of this evidence had in fact existed already during the initial trial, but the military court refused to take it into account regardless of being aware of it. However, it is true that also other, new and aggravating evidence came to light later. This evidence was not taken into account and suitably placed in the contemporaneous historical context by the authors of the historical expertise, consisting of two independent parts ${ }^{46}$ and written by two authors, which represented the historical basis for the proposal on the renewal of the criminal proceedings in the "Rožman Case". It is a fact that this evidence - especially certain published diplomatic and military documents originating in Germany, Italy

41 The problem of the actions of (especially) the Catholic Camp at the beginning of the Axis Power aggression against Yugoslavia was explored in Bojan Godeša, Čas odločitev. Katoliški tabor in začetek okupacije [Time of Decisions: Catholic Camp and the Beginning of the Occupation] (Ljubljana: Mladinska knjiga, 2011).

42 Referring to Bishop Rožman.

43 Janko Pleterski, "Uvodna beseda," ["Introduction”] in: Škof Rožman v zgodovini, eds. Janez Stanovnik, Slavko Grčar and Hardvik Pirnovar (Ljubljana: Društvo piscev zgodovine NOB Slovenije, 2008), 6 .

44 Repe, Milan Kučan, 431, 432.

45 Ibid.

46 France M. Dolinar and Tamara Griesser-Pečar, Rožmanov proces [The Rožman Process] (Ljubljana: Družina, 1996). 
and the Vatican - would have made it much easier for the court, had it had these documents at its disposal at the time, to pass a much more transparent judgement, which would have been, from the viewpoint of its historical credibility, impossible to refute even according to the legal order and values of the today's Slovenian society. ${ }^{47}$ Even though the results of this research had not yet been presented at the time, President Kučan's opinion, expressed in the correspondence with the Vatican State Secretary Cardinal Sordano, was that the reburial should not be based on the legal and political rehabilitation of Bishop Rožman. Instead it should be seen merely as a pious act, stemming from Rožman's right to his grave. ${ }^{48}$ In view of the most recent historiographical discoveries, this opinion has nevertheless turned out to be much more appropriate, also from the viewpoint of the historical credibility.

In the discussion Slovenian Historical Burden that the German historian Joachim Hösler, who also wrote a few monographs on the Slovenian history, prepared for the needs of the German politics, Hösler establishes the following:

During World War II nationalism meant survival for the Partisans and the Home Guard. Today it functions as an ideology of reconciliation. In this regard the 'national unity' and 'collective identity' are merely illusions of reality, supported by intellectuals and politicians. Democratic and plural societies cannot and simply do not need to become 'one'. Much can be achieved already with an open and civilised discussion about the conflict of interests". 49

However, this way of shedding light on the wartime developments has not prevailed in the Slovenian society. It seems that the opinion closest to Hösler's - at least as far as the question of the national reconciliation is concerned - is that of Spomenka Hribar, who, in her essay Guilt and Sin in the middle of the 1980s, established the problem of reconciliation as a socially-relevant question. ${ }^{50}$ In the Razgledi magazine in 1994, Hribar argued for a completely different standpoint with regard to the role of reconciliation, as it was understood (especially) in the Church circles. She emphasised the following:

"Not many issues involve as many misunderstandings as the question of reconciliation, since the dominant opinion is that reconciliation: 1) is related to the past and it is supposedly meant to 'manage' the past affairs; and 2) concerns the wartime opponents, which should thus 'reconcile, and they should achieve this by admitting to a single interpretation (the Truth) about

47 Bojan Godeša, "O političnem delovanju ljubljanskega škofa dr. Gregorija Rožmana v prvih mesecih okupacije," ["On the Political Activity of the Ljubljana Bishop Dr Gregorij Rožman in the First Months of the Occupation"] Zgodovinski časopis, No. 2 (2013): 152-70. Bojan Godeša, "O škofovi odgovornosti," ["On the Bishopss Responsibility"] Mladina, 31 July 2015, 29. Bojan Godeša, "Enega mita ni mogoče zamenjati z drugim," ["One Myth Cannot be Replaced by Another"] (Interview by Ženja Leiler), Delo, 27 May 2016, 21.

48 Repe, Milan Kučan, 431, 432.

49 Joachim Hösler, "Sloweniens historische Bürde," Aus Politik und Zeitgeschichte, 2006, 46.

50 Spomenka Hribar, "Krivda in greh," ["Guilt and Sin”] in: Kocbekov zbornik, ed. Dimitrij Rupel (Maribor: Založba Obzorja, 1987), 6-68. 
the dispute. According to such reasoning it is logical that reconciliation is actually supposed to involve the political rehabilitation or even victory of what has until now been the unstated truth against the opposite side, or that the 'new' truth is supposed to be a kind of a combination of both interpretations. As this is impossible, of course, we can establish that reconciliation is an unattainable goal, a dream, an ideology, an eternal imperative, the work of Sisyphus, and after all - 'that reconciliation!' And what does reconciliation have to do with the past? Nothing at all! The past is what it used to be! There is nothing to change and revise. It is the task of the historians to explore the past and keep explaining it again and again, from new viewpoints. Meanwhile, reconciliation matters to us, here and now, because we have a future ahead of us. It is a new beginning, a consensus that the future will not be like the past, because that would be devastating! Reconciliation is not the eradication of differences, but rather quite the opposite - an a priori assent to these differences. Therefore it presupposes diversity: various political standpoints, obstacles, interpretations of history and one's own role in it, ideas and dreams about the future, personal truths, political interests - the only presupposition of all these dissimilarities is that people - those who subscribe to and declare all these legitimate and humanly justifiable differences - wish to and want to live in harmony. In this sense-and only in this sense - reconciliation also involves an attitude towards the past, as it consciously puts an end to one period and begins another. If this is not so - if reconciliation does not exist - the old keeps dragging on!'51

\section{Sources and Literature}

Archive sources:

- SI AS, Arhiv Republike Slovenije:

- SI AS 1931, Republiški sekretariat za notranje zadeve.

\section{Literature:}

- "Izjava Predsedstva ZZB NOB Slovenije o vrednotah, sprejeta na seji 6. oktobra 2015.” [Statement of the Presidency of the ZZB about the values of the National Liberation Struggle of Slovenia, adopted at the session on 6 October 2015] Sporočila. Zveza združenj borcev za vrednote NOB Slovenije. October 2015, 10.

- "Milan Kučan.” In: Slovenija in pika!, eds. Boštjan Furlan, Ožbej Peterle and Marko Balažic, 189213. Ljubljana: Cankarjeva založba, 2016.

- "Z narodno spravo - konec državljanske vojne?.” Borec. Revija za zgodovino, antropologijo in književnost 42, No. 5-6-7 (1990): 582-716.

- Čepič, Zdenko, Tone Ferenc, Aleš Gabrič, Bojan Godeša, Boris Mlakar, Dušan Nećak, Jože Prinčič, Janko Prunk, Božo Repe, Anka Vidovič-Miklavčič, Peter Vodopivec and Milan Ževart. Ključne značilnosti slovenske politike v letih 1929-1955. Znanstveno poročilo. [Key Characteristics of the Slovenian Politics 1929-1955. Scientific report] Ljubljana: Inštitut za novejšo zgodovino, 1995.

- Delo, 5 March 1990, "Narodna umiritev kot pogoj za mirno sožitje." ["National Appeasement as a Condition for Peaceful Coexistence"]

- Dolinar, France Martin and Tamara Griesser - Pečar. Rožmanov proces. [The Rožman Process] Ljubljana: Družina, 1996.

51 Spomenka Hribar, “'Sprava ni konsenz o preteklosti, temveč o prihodnosti' (Kaj se je zgodilo s slovensko zgodovino? (6. del))," ["Reconciliation is Not a Consensus about the Past, It is a Consensus about the Future' (What has Happened to the Slovenian History? (Part 6))"], Razgledi, 13 May 1994, 18,19 . 
- Dolinar, France Martin. Resnici na ljubo. Izjave ljubljanskih škofov o medvojnih dogodkih. [Truth Be Told. Statements of the Ljubljana Bishops about the Wartime Events] Ljubljana: Družina, 1998.

- Družina, 8 July 1990, 13, "Za globlje razumevanje sprave. Izjava komisije Pravičnost in mir (prof. dr. Anton Stres)." ["For a Deeper Understanding of Reconciliation. The Statement of the Justice and Peace Commission (Professor Dr Anton Stres)"]

- Godeša, Bojan. "Enega mita ni mogoče zamenjati z drugim." ["One Myth Cannot be Replaced by Another"] (Interview by Ženja Leiler). Delo, 27 May 2016.

- Godeša, Bojan. "Lojze Ude in poskus vzpostavitve premirja med drugo svetovno vojno." ["Lojze Ude and the Attempt to Establish a Cease-Fire During World War II"] Acta Histriae 21, 3 (2013): 283-90.

- Godeša, Bojan. "O političnem delovanju ljubljanskega škofa dr. Gregorija Rožmana v prvih mesecih okupacije." ["On the Political Activity of the Ljubljana Bishop Dr Gregorij Rožman in the First Months of the Occupation”] Zgodovinski časopis 67, No. 2 (2013): 152-70.

- Godeša, Bojan. "O škofovi odgovornosti." ["On the Bishop's Responsibility"] Mladina, 31 July 2015.

- Godeša, Bojan. "Social and cultural aspects of the historiography on the Second World War in Slovenia," Sozialgeschichte und soziale Bewegungen in Slowenien / Social History and Social Movements in Slovenia. Mitteilungsblatt des Instituts für soziale Bewegungen 41, (2009): 111-25.

- Godeša, Bojan. Čas odločitev. Katoliški tabor in začetek okupacije. [Time of Decisions: Catholic Camp and the Beginning of the Occupation] Ljubljana: Mladinska knjiga, 2011.

- Godeša, Bojan. Spremembe v vrednotenju druge svetovne vojne na Slovenskem po padcu berlinskega zidu. [Changes in the Assessment of World War II in Slovenia after the Fall of the Berlin Wall] Lecture at the Historical Seminar of the Scientific Research Institute of the Slovenian Academy of Sciences and Arts in Ljubljana on 12 May 2016. Acquired on 10 June 2016. https://www.youtube.com/ watch?v=KkpyJ2GKuI8.

- Govor predsednika Vlade RS Janeza Janše |SDS. [A speech by the President of the Government of the Republic of Slovenia Janez Janša | SDS] Acquired on 22 June 2016. http://www.sds.si/novica/ govor-predsednika-vlade-rs-janeza-janse-3264.

- Gradivo otvoritvenega zasedanja Svetovnega slovenskega kongresa, Ljubljana, 27. in 28. junija 1991. Ljubljana: Svetovni slovenski kongres, Konferenca za R. Slovenijo, 1994.

- Grgičc, Jožica. "Kočljivi medvojni položaj ljubljanskega škofa. Zgodovinarja Dolinar in Godeša o Rožmanu." ["The Awkward Wartime Position of the Ljubljana Bishop. Historians Dolinar and Godeša on Rožman”] Delo, 12 April 2013.

- Hösler, Joachim. "Sloweniens historische Bürde." Aus Politik und Zeitgeschichte, 2006, 46. Acquired on 22 June 2016. http://www.bpb.de/apuz/29421/sloweniens-historische-buerde?p=all.

- Hribar, Spomenka. "Krivda in greh." ["Guilt and Sin"] In: Kocbekov zbornik, ed. Dimitrij Rupel, 6-68. Maribor: Založba Obzorja, 1987.

- Hribar, Spomenka. "'Sprava ni konsenz o preteklosti, temveč o prihodnosti' (Kaj se je zgodilo $s$ slovensko zgodovino? (6. del))." ["'Reconciliation is Not a Consensus about the Past, It is a Consensus about the Future' (What has Happened to the Slovenian History? (Part 6))"] Razgledi, 13 May 1994.

- Jamnik, Anton. "Kdor trdi, da sprava ni možna, je obupal nad človekom.” ["Whoever Claims that Reconciliation is Impossible has Given Up on Humanity"] Slovenski cas (monthly supplement of the Družina newspaper), June 2015.

- Kolednik, Aleksander. "Griesser - Pečarjeva: Rožman si je prizadeval, da bi narod s čim manjšimi izgubami prebrodil vojno" ["Griesser-Pečar: Rožman strived to ensure that the nation could make it through the war with as few losses as possible"] (11 April 2013). Acquired on 10 June 2016. http:// siol.net/novice/slovenija/griesser-pecarjeva-rozman-si-je-prizadeval-da-bi-narod-s-cim-manjsimi-izgubami-prebrodil-vojno-159685.

- Kos, Stane, Stalinistična revolucija na Slovenskem, I. Rim: Samozaložba, 1984.

- Levstik, Vinko. Tri odprta pisma k narodni spravi. Rim, 1968.

- Milan Kucan; Spravna slovesnost v Koćevskem rogu [Milan Kučan; the reconciliatory ceremony in Kočevski rog]. Acquired on 10 June 2016. http://www2.gov.si/up-rs/2002-2007/bp-mk.nsf/dokumenti/08.07.1990-90-92. 
- Mlakar, Boris. "Protirevolucionarni tabor in konec vojne." In: Slovenska novejša zgodovina. Od programa Zedinjene Slovenije do mednarodnega priznanja Republike Slovenije 1848-1992, eds. Jasna Fischer, Žarko Lazarević, Ervin Dolenc, Jurij Perovšek, Bojan Godeša, Zdenko Čepič and Aleš Gabrič, 773-78. Ljubljana: Mladinska knjiga, 2005.

- Pesek, Rosvita. Bučar. Celovec: Mohorjeva, 2016.

- Pleterski, Janko, "Uvodna beseda." [“Introduction”] In: Škof Rožman v zgodovini, eds. Janez Stanovnik, Slavko Grčar, Hardvik Pirnovar, 5-6. Ljubljana: Društvo piscev zgodovine NOB Slovenije, 2008.

- Pleterski, Janko. "O NOB in spravi." ["On the National Liberation Struggle and Reconciliation"] In: Narodnoosvobodilni boj v slovenskem narodnem spominu: slovenski zbornik 2007, ed. Janez Stanovnik, Slavko Grčar and Hardvik Pirnovar, 23-31. Ljubljana: GO ZZB NOB Slovenije, 2007.

- Pučnik, Jože. "Sprava kot izhodišče za civilno rast Slovencev iz naroda v državo." ["Reconciliation as the Basis for the Civil Growth of Slovenians from a Nation into a State"] In: Biti to kar si. 33. študijski dnevi Draga 98, eds. Sergij Pahor, Saša Martelanc, Marij Maver. Trst: Mladika, 1999.

- Repe, Božo. "Sprava kot kulturni boj." ["Reconciliation as the Cultural Struggle"] In: Onstran demokracije. Izjave in stališče Liberalne akademije po letu 2005, ed. Božidar Flajšman, 93-101. Ljubljana: Liberalna akademija, 2009.

- Repe, Božo. Jutri je nov dan. Slovenci in razpad Jugoslavije. [Tomorrow is Another Day. Slovenians and the Dissolution of Yugoslavia] Ljubljana: Modrijan, 2002.

- Repe, Božo. Mimo odprtih vrat. Izbrani dokumenti o dejavnosti okupatorjevih sodelavcev na Slovenskem. [Past the Open Door. Selected Documents about the Activities of the Occupiers' Collaborators in Slovenia] Ljubljana: Založba Borec, 1988.

- Repe, Božo. Viri o demokratizaciji in osamosvojitvi Slovenije. 2. del. - Slovenci in federacija. [Resources on the Democratisation of Slovenia and its Attainment of Independence. Part 2 - Slovenians and the Federation] Ljubljana: Arhivsko društvo Slovenije, 2003.

- Rotar, Braco. "Sprava namesto zgodovine," [“Reconciliation Instead of History”] Razgledi, 27 May 1994.

- Roter, Zdenko. Padle maske. Od partizanskih sanj do novih dni. [Masks Removed. From the Partisan Dreams to the New Days] Ljubljana: Sever \& Sever, 2013.

- Rozman, Branko. "Vizije in meje narodne sprave." In: Čez prepad revolucije. 24. študijski dnevi Draga 89, 81-111. Trst: Mladika, 1990.

- Slabe, Janja. "Narodna sprava v slovenskih časopisih." ["National Reconciliation in the Slovenian Press"] Borec. Revija za zgodovino, antropologijo in književnost 58, 630-634 (2006): 9-60.

- Stanovnik, Janez. "Obvojni poboji in narodna pomiritev." ["Wartime Executions and the National Appeasement"] In: Slovenski zbornik 2014. Narodnoosvobodilni boj in današnji čas, eds. Janez Stanovnik, Slavko Grčar, Matjaž Kmecl, Jože Pirjevec, Maca Jogan, Božo Kovač and Mitja Klavora (Ljubljana: Zveza združenj borcev za vrednote NOB Slovenije, 2014), 91-99.

- Vrtovec, Jernej. Vloga nadškofa Šuštarja pri osamosvojitvi Slovenije. [The Role of Archbishop Šuštar in the Attainment of the Slovenian Independence] Celje: Celjska Mohorjeva družba, 2016.

\begin{tabular}{c}
\hline Bojan Godeša \\
\hline SPRAVA NAMESTO ZGODOVINE \\
\hline P O VZE T E K
\end{tabular}

Kot temeljno značilnost razčiščevanja medvojne preteklosti v zadnjih 25 letih lahko prizadevanja za spravo v sintetični obliki sklenemo z ugotovitvijo: $\mathrm{z}$ vsako spravno deklaracijo se nasprotja in ideološke delitve v slovenski družbi le še poglabljajo.

Kdo je odgovoren za tako stanje v slovenski družbi? Odgovor sicer ne more biti povsem enoznačen, glede na to, da se zdi, da takšne razmere na neki način pravzaprav ustrezajo mnogim na obeh straneh. Razlike so bile razvidne že v opredelitvi izhodišč za spravni proces v omenjenih izjavah predsedstva SRS in Slovenske škofovske konference. Medtem, ko prva izpostavlja predvsem pietetni vidik spravnega de- 
janja ter priporoča depolitizacijo pri reševanju perečih vprašanj iz preteklosti, pa je RKC v tem pogledu zelo odločno postavila zahtevo po prevrednotenju preteklosti, kar so utemeljevali, da "edino resnica nas more osvoboditi, biti podlaga za spravo in omogočiti pot $\mathrm{k}$ pomiritvi". Kljub tem zelo očitnim razlikam, je danes vendarle že povsem jasno, da je jedro problema vendarle predvsem v načinu obravnave preteklosti, o kateri v slovenski družbi sicer obstajajo zelo razlikujoče se ocene. Glede na to, da je do dogodkov, povezanih s padcem berlinskega zidu, prevladovala pristranska podoba druge svetovne vojne na Slovenskem, je postalo jasno, da jo je vsekakor treba interpretativno posodobiti in spraviti v novo ravnovesje. O tem pravzaprav ne bi smelo biti nobenega dvoma. Vendar se v osnovi popolnoma legitimna zahteva po razčiščevanju preteklosti ni razvila v prevlado konstruktivnega dialoga, ki bi bil z nepristranskim, znanstveno neoporečnim pristopom usmerjen $\mathrm{k}$ celoviti obravnavi medvojnega dogajanja. Kmalu se je namreč zahteva "po spravi, katere pogoj je resnica", sprevrgla v boj za interpretativno prevlado v slovenski družbi, ki ne upošteva vedno znanstvenih meril.

Razlaga zagovornikov medvojnega s kolaboracijo obremenjenega protikomunističnega tabora se je tudi v delu slovenskega zgodovinopisja po osamosvojitvi uveljavila kot verodostojna interpretacija medvojnega dogajanja. Vendar so najnovejše poglobitve $\mathrm{v}$ to problematiko, ki jih je opravil pisec teh vrstic, "emigrantsko" tezo v celoti ovrgle, in to ne le kot pristransko in črno-belo, temveč kot popolnoma neverodostojno razlago, ki nima podlage $\mathrm{v}$ znanstveno preverljivih dejstvih. Najbolj prepričljivo se je neverodostojnost te interpretacija pokazala $\mathrm{v}$ zahtevi po sodni in politični rehabilitaciji ljubljanskega škofa dr. Gregorija Rožmana.

Eden ključnih razlogov za predlog po obnovitvi procesa proti Rožmanu naj bi bili tudi "novi dokazi”, ki naj bi seveda razbremenjevali obsojenega škofa. Vendar v zgodovinski ekspertizi Rožmanov proces, ki je predstavljala historiografsko podlago predloga za obnovo kazenskega postopka v "zadevi Rožman", avtorja nista upoštevala oz. nista na ustrezen način umestila v tedanji historični kontekst vseh dosegljivih dokumentov. Dejstvo je, da bi ti dokumenti, ki so bili odkriti kasneje, sodišču, če bi z njimi razpolagalo, olajšali podati mnogo bolj transparentno obsodbo. Te ne bi bilo moč na podlagi historiografske verodostojnosti zavrniti niti s stališč pravnega reda, niti z vidika političnih vrednot, na katerih temelji današnja slovenska demokratična in pluralna družba. Rožman je bil leta 2007 in nato 2009 sicer sodno rehabilitiran zaradi očitnih postopkovnih napak v procesu leta 1946. Sicer pa na podlagi omenjenih razkritij sodobne slovenske historiografije za Rožmanovo politično rehabilitacijo ne obstajajo nikakršni razlogi, ki bi izvirali iz znanstveno preverljivih dejstev. 